DOI: $10.15503 /$ jecs20151.207.216

\title{
TEMPORALITY AND PERMANENCE IN ROMANIAN PUBLIC ART
}

\author{
MaRia-Judit BaLKo \\ Centre of Excellence in Image Studies, University of Bucharest, \\ Bd. Regina Elisabeta 4-12, Bucharest, Romania \\ E-Mail adress: juditbalko@yahoo.com
}

(1) $(\Theta \Theta \Theta$

\begin{abstract}
This paper analyzes the relationship between permanent monuments and temporary art projects, as temporality is one of the strategies employed by Romanian artists to counterbalance the support that the Romanian state has shown only towards monuments and memorials dedicated to affirming its value. The complex nature of public art requires a careful consideration of the different dimensions this practice employs, and for that the Western debate on this matter can be a reference point in understanding Romanian public art. We will be looking at possible aspects of the functions of these two main directions in Romanian public art, as they stand methodically one in opposition to the other, in connection with the texts of Piotr Piotrowski (Art and Democracy in Post-communist Europe, 2012) and Boris Groys (Art Power, 2008).
\end{abstract}

Keywords: public art, post-communism, monument

On the $10^{\text {th }}$ of October 2011, any passer-by walking along the Victory Avenue (Calea Victoriei) in Bucharest would come across an unusual manifestation in front of the building of the Royal Foundation, now the Central University Library of Bucharest. Near the equestrian statue of Carol I (which was made by the sculptor Florin Codre and only recently unveiled in 2010), a group of performers were kneeling on the pavement, mimicking the position of the horse above, one leg raised ${ }^{42}$. A living sculpture, frozen in its movement, and a bronze equestrian stood for two hours a day in an open dialogue between the immobility and stability of history cast in bronze and the variability of the past reflected in a temporary artistic intervention. At the same time, in the Free Press Square (Piața Presei Libere), the same passers-by would encounter a large red granite plinth which is now empty but on which, until 1990, there stood a six meter tall bronze statue of Lenin. On the base of the plinth, a large photographic print of the same statue laid face down on the granite tiles ${ }^{43}$. As different as these works of art may seem, the statue, the performance and the print all come together under the name of public art.

We will not venture into defining this practice, as it is a complex and controversial field which includes various forms of artistic expression (from sculpture

42 The intervention is part of the series of performances Dacă voi nu ne vreți, noi vă vrem (If you don't want us, we want you) initiated by Alexandra Pirici.

43 Lenin's sleep, temporary artwork made by artist Mihai Zgondoiu in the framework of public art project Proiect 1990. 
to performance and permanent, as well as temporary projects). However, we will point out some of the questions raised by the debate on public art in Western culture. Starting with the sixties, public art received strong governmental support throughout North America and Western Europe. For this reason, it developed in more than one direction, from large abstract sculptures in public places, to temporary interventions and participatory art, but it was only in the late eighties and the beginning of the nineties that this practice came under scrutiny. One of the texts which marked this shift and which opens up new ways of thinking about public art was Patricia Philips' essay "Out of Order: The Public Art Machine" from the 1988 Artforum. The author was at that time one of the few to adopt a critical position towards public art when most of the statements in this field came from organizers, commission bodies, or from those involved in public art, their discourse thus being thought to promote the field rather than to offer a critique. Philips remarks that although public art in the late $20^{\text {th }}$ century has become a stable artistic discipline, there is a lack of definitions and of "constructive theory" in this field. Philips complains that "the making of public art has become a profession, whose practitioners are in the business of beautifying, or enlivening, or entertaining the citizens of modern American and European cities. In effect, the mission of public art has been reduced to making people feel good - about themselves and where they live" (Philips, 1988, p. 191). P. Philips argues that the bureaucratic processes which surround this form of art have led to a diminished artistic quality and that the democratic process of a selection panel does not ensure that the best work is chosen, but rather the one raising the fewest questions. The fact that people outside the world of art are included in selection committees (such as representatives of the community or the funding bodies involved in various projects) brings the relevance of the work of art for the broadest public possible among the top requirements for an artwork to be chosen. P. Philips argues that imposing an "all-inclusive" demand on the public art can have an oppressive effect, as the universal character is inherent to the work, if the art fulfils its aim, and cannot work as an $a$ priori requirement as "art is an investigation, not an application"( Philips, 1988, p. 193). Critic Patricia Phillips extends this inquiry, offering not an answer, but more questions: "which is the community that should have the most say in "approving" the design of the Vietnam War Memorial in Washington, D.C.? Veterans? The family members of men killed or missing in action? The group of office workers and government bureaucrats who work nearby? The public at large, who might feel a sense of possession of this tragic, poignant space?" (Philips, 1988, p. 194).

The author points out that when considering public art, one should bear in mind not only, or rather especially not, its location, or public funding, but its connection to and engagement with public life and the public sphere, underlining the fact that the public dimension bears social and political significance that is not necessarily conveyed to a work of art just because the latter is located in an area that provides free access to all. The public dimension of art is predicated through the questions it chooses to raise and not on its accessibility or number of viewers.

The issues raised by P. Philips were taken some steps further during the following years, and public art was analyzed not only from an artistic and historical 
point of view but in connection to philosophy, sociology and cultural geography as well. More recently, Claire Bishop offers, in "Artificial Hells", a new reading on the development of participatory art, thus opening up new perspectives in understanding the field of public art. Investigating the socially involved art projects, Bishop points out that these types of projects are currently evaluated through their social outcomes, in measurable and concrete goals, and not through their aesthetic qualities, although participatory art projects pertain to contemporary art. She draws attention to the fact that the artistic values of the participatory projects are overlooked and are analyzed by using ethical criteria, which means that the analysis is made by comparing these projects among themselves and that they are therefore criticized by the models of collaboration they develop, be they good or bad. What is notable in C. Bishop's text is that she points out how in the effort to 'sell' an art project and receive funds through slogans which affirm what art does for the society, like "increasing employability, minimizing crime, fostering aspiration", the artistic component is left out, and no stress is put on the "artistic experimentation and research as values in and of themselves" (Bishop, 2012, p. 13). Through this, C. Bishop also points out the importance of analyzing these projects as art, since this is the field in which they are developed, and we would continue saying that this is a statement which stays true for the entire field of public art, where the question of what art does for society in measurable and verifiable results sometimes voids the importance of how it manages to do so.

The debate around public art in Western culture offers an insight into the complexity of this practice, but nonetheless it tells us little about what public art is in Romania, where this artistic practice received little attention in the first years after the revolution and only recently has come under the spotlight.

We will explore the development of public art in Romania after 1989 from the perspective of the relationship between permanent public art and temporary public art projects, two of the main directions in Romania, as the former is mainly supported by the state institution (through permanent sculpture), and the latter by private and artistic non-profit organizations (through temporary interventions). We will be looking into two of the most controversial monuments erected in Bucharest in recent years (the monument of Carol I, in 2010 and the sculpture of emperor Traian, in 2012, both of them on the Victory Avenue) and a temporary public art project, with the aim to understand what their possible functions and roles are in contemporary Romanian public life.

We start from the premise that under the communist regime, there was no public space, reason for which this practice is a new artistic genre that originated in Romania after 1989. Nevertheless, before 1989, there was an art scene as well as active artists who continued their practice after the revolution. The Professional union of artists which controlled the artistic production under the communist regime continued to function with little changes in the first ten years after the revolution, though its power has gradually been coming to a decline during the last fifteen years, through an increase of activity in the artistic sector after the year 2000 - the emergence of private galleries and NGOs dedicated to supporting contemporary art. Therefore, in our analysis, we will look at the development of 
public art in Romania in connection to two different understandings of the events of 1989. On the one hand, there is the perspective supported by Piotr Piotrowski, which views the post-communist states as evolving from the communist ones, and on the other hand that of Boris Groys, who considers revolution to be the opposite of evolution, a return to a previous condition, to the moment before everything started to go in a wrong direction.

Boris Groys analyzes the post-communist condition from a broader perspective in connection with cultural studies and postmodernist sensibility, and argues that the historic process that led to the current situation is a direct trajectory which started with pre-modernism and continued with modernism and postmodernism, while the shift from pre-communism, to communism and then to post-communism takes a different direction. According to B. Groys, the radicalism of the communist project, which situated itself at the end of history, did not allow the post-communist countries to evolve past this moment, but called for a return to the past, to the moment before the communist revolution, "from the posthistorical, postapocalyptic time, back to historical time" (Groys, 2008, p. 163). This return to the capitalist system also required that the former communist countries redefine their cultural identities, which explains the rebirth of nationalism in these nations. "They are required to demonstrate, for example, their specific Russian or Ukrainian characteristics, which, as I have tried to show, these post-Communist subjects do not have and cannot have because even if such cultural identities ever really existed, they were completely erased by the universalist Soviet social experiment" (Groys, 2008, p. 163). This need to redefine one's national identity is also considered by B. Groys as a response to the quest for difference and diversity which characterizes the cultural taste of the West, an aesthetic taste which on the one hand is very open and inclusive, but on the other hand rejects everything that is universal, homogeneous, uniform, and in particular the communist grey aesthetic. These aesthetic preferences developed in connection with the market, which led to defining one's own cultural identity through the commercialization, through the transformation of this cultural identity in a commodity, in a product that can be sold "on the international media and touristic markets" (Groys, 2008, p. 158). And this is where, according to B. Groys, postmodernism meets post-communism as, although in different ways, both aim for aesthetic diversity and both are controlled by the market.

Piotr Piotrowski adopts a different position and views the post-communist condition not as a break from the past, but as the transition from the communist system to the capitalist one: "Contrary to what one would expect, the post-communist condition does not require a rejection of communism and a return to the 'former' state. In fact, it can signal a certain type of continuity, if not of symbols, then certainly of the model of thought, customs and habits, as well as ways of wielding power by the former adversaries of the fallen system, now mainly identified with the political right" (Piotrowski, 2012, p. 44). P. Piotrowski adopts a more nuanced position, arguing that the communist ideology was not put into practice in the same way in countries in Eastern Europe and thus not building a homogenous history, but more different national perspectives which have particular characteristics of their own. And in the same way, after 1989, the evolution towards 
democracy took different directions. What connects the former communist countries is the fact that none of them have reached democracy:

"The current political system in Central Europe could be described as post-communist democracy, or democracy that formally resembles liberal democracy, but which is governed by different mechanisms of ownership and exclusion. [...] it exhibits different forms of privatization of the public space, different relations between critique and affirmation, what is public and what is private, differently constituted publics. Moreover, the situation varies from country to country. It is a different system in the Czech Republic, the most secular state in the world, and in Poland, a country dominated by a rather conservative form of Catholicism "(Piotrowski, 2012, pp. 66-67).

Looking back at Romania, we will use Piotrowski's and Groys' interpretations of the post-communist condition as possible lenses through which the current situation in Romanian public art can be understood.

The monument of Carol I was unveiled in December 2010, on Victoria Avenue (Calea Victoriei), near the Revolutionary Square. Made by Florin Codre, the sculpture is an equestrian dedicated to the first king of Romania, Carol I (king between 1866 -1914), placed in front of the building of the Royal Foundation and across from the National Museum of Art of Romania (the former Royal Palace). The statue was thought as a replacement for Ivan Meštrović's monument of Carol I, which stood in the same place and which was removed when the communist regime came to power, in December 1947. The Croatian sculptor won the contest held in 1936 for the design of a monument dedicated to Carol I, and the statue was unveiled on the $10^{\text {th }}$ May 1939. Because Meštrović' s sculpture was destroyed and the state's negotiations with his descendants to buy another copy failed, a new sculpture was commissioned by the municipality of Bucharest and was inaugurated on the $6^{\text {th }}$ December 2010, five days later than it was originally planned, as the unveiling should have happened on the $1^{\text {st }}$ December, the Romanian national day.

From an aesthetic point of view, the sculpture is not a success, as the artist chose an artistic expression that it is not entirely classical, nor innovative, but something that hangs in between, opting for something which is recognisable and at the same time consecrated, but also wanting the work to be recognised as a contemporary one, which is obvious in the lenient manner in which the artist approaches the representation - the lack of some of the details in the clothing. Without being a replica, the general aspect of Codre's sculpture resembles the one made by Meštrović a lot, and the changes made by Codre are not to the advantage of artistic expression. Two of the most striking differences are the fact that the new sculpture is larger than the previous one and is therefore in no harmonious relationship with the adjacent building, as well as the horse's tail, which has received a lot of criticism in Codre's version.

Apart from its artistic value, another perspective of interpretation is given by questioning its function as public art. A possible answer for this is provided by Boris Groys' reading of the post-communist condition. The present regime tries to erase the communist period and returns to the symbols and values of ante-communist Romania. Thus, in this regard, the sculpture has a restorative function; it 
connects the present political system with the pre-communist one, and thus legitimates it, by affirming a continuity of values between the two systems, before and after communism. It is also part of the nationalist project, to fill the void left by the removal of public symbols (which was typical of the communist regime) with old or new values.

The monument is surrounded by some controversies, and opinions are divided between those who acclaim it, as its presence in the public space stands for a symbolic reclaim of the Romanian royalist past, whose traces were thoroughly removed from the public space during the communist regime, and those who contest the sculpture, claiming that the work of art was a poor replica of the original. Thus, in one case, the sculpture is judged by what it does, or attempts to do (which is to construct a national identity and continuity of values) and, in the other, by how it does it (the artistic expression).

Although, in theory, the monument stands for the great values of the pre-communist political system which are reinstated by the current system, the process of commission which sits behind the erection of this monument is more connected to the communist regime. The monument was commissioned without any contest to the sculptor Florin Codre and there were disputes between the municipality and the Ministry of Culture, as the Ministry of Culture also had on its agenda a monument dedicated to Carol I, but had in mind a different location. As the laws that regulate this practice are in some aspects ambiguous and public space is managed by the municipality, the monument was placed according to the decision of the institution at its previous location, but closer to the Royal Foundation building.

The process of commissioning that stands behind this monument is not an exception in Romania, but rather the rule, as in most cases the process of selection, if any, is to say the least questionable or promoted only in certain artistic groups, thus making it difficult for young artists to participate. It is for these reasons that these commissions ended up being given to the same few artists. One of the most poignant cases in this direction is the Memorial of Rebirth, in Bucharest, unveiled in 2005 and made by Alexandru Ghilduş. In this case, there was an open call for projects, as well as a jury, but the selection was invalidated by Ion Iliescu, president of Romania at the time, who personally chose the project that he liked from the ones submitted by the artists, as reporter Maria Bercea relates in an article in "Revista 22", which reveals the entire process that led to the erection of the monument.

Another monument which raised controversies was the statue of Emperor Traian made by the sculptor Vasile Gorduz and unveiled in 2012. The two metres high bronze sculpture was placed on a small plinth on the steps of the National Museum of History. The Emperor Traian is represented standing, nude and with his hands lightly stretched out, holding in his arms, but without actually touching, a female wolf whose head is a three-dimensional version of the dacia tribal flag symbol, a wolf head with a serpent tail. The sculpture is a symbolic representation of the birth of the Romanian people, a mix between the local known as daci and the Romans who conquered this region in 106 A.D. under the rule of Emperor Traian. As the previously mentioned monument, this sculpture also has the role to reaf- 
firm a national identity which can be traced back 2000 years. But in this case, the state is not appealing to the pre-communist symbols, but to more powerful ones, the tracing of the Romanians' roots back to the Romans (which influenced the Romanian language, its Latinity thus becoming a strong point in national discourses), and to the Daci who were described by the historians of the time as being fearless and brave.

What is interesting about this artwork is not what it does and what it evokes, but rather how it does it, the method the artist chose to use in order to deliver its message. The artist's aim was not to create a sculpture of a great emperor, but to create an image of the 'birth' of a people. For that, the sculptor turned to the stylistic expression of the ancient classical Roman art in the representation of Traian and also in the representation of the female wolf, whose artistic expression is drawn from the known sculpture of Romulus and Remus being suckled by a female wolf. Therefore, the sculpture also makes a reference to another 'birth', the mythological foundation of Rome. What the sculpture brings forth is the artistic composition, the strange assemblage of the component elements (the male body, the female wolf and the dacic wolf symbol), which make me think of a De Chirico painting where everything is still and quiet. This combination works due to the continuity of the artistic expression. The nudity of the emperor, which raised a lot of discussions in the press, is a daring gesture that breaks the sculpture from the conventional and traditional realm of monuments and places it into the world of contemporary art.

Most of the permanent works of public art installed after 1989 were commissioned by state institutions as commemorative monuments with the aim to affirm a national identity and most of them resorted to conventional expressions, because either the artists or the commissioners had chosen the safer path of established artistic expression than the unpredictability of the new. This situation was partly due to the fact that the institutional mechanisms which were behind it were drawn from the communist regime, and partly due to the fact that the Union of the Professional Artists which survived the change of regime was reluctant to change in both its system of organization and in the promotion and support of artistic practices.

Aside from this practice which filled the Romanian cities with a lot of busts and 'heroes on horses', new forms of public art emerged, bringing into question the public space and the role of art in the public. It was a constant growth of this new direction in Romanian public art, from the single, artist initiated, and short term interventions of the nineties (such as the subREAL ${ }^{44}$ intervention in Bucharest along "The Victory of Socialism Avenue," from August 1990, titled "East-West Avenue" or Matei Bejenaru's project Alexandru cel Bun (1994 - ...) in Iaşi) to more complex projects after the year 2000, and as more artists became interested in exploring this field, the construction of a long term platform to support it became necessary. Although this practice is entirely developed through private initiati-

44 subREAL was founded in April 1990 by Călin Dan and Dan Mihălțianu. Iosif Király joined the group in February 1991. In August 1993 Dan Mihălțianu left subREAL, which operates since then as an artist-duo. 
ves (either artists or non-profit organizations) and sometimes supported by public funds, in the last ten years it became more visible and present in the public space. In this direction, several projects were developed, such as "Visible City", organized by Alt Art Foundation in Cluj, since 2010, "Project 1990", initiated by artist Ioana Ciocan in Bucharest, which was active between 2010 and 2014, the Expanded Space public art program, developed in Bucharest by Volume Art Association since 2011, and "Waiting spaces", active in Timişoara since 2012 and initiated by the Simultan Association and by the h.arta Group, all of them having developed temporary interventions.

One of the first projects which sought to open a wider debate regarding the public space and to raise awareness of the precarious conditions of this space in post-communist Romania was Spațiul Public Bucureşti | Public Art Bucharest 2007, curated by Marius Babias and Sabine Hentzsch.

The project was developed between 20 April 2007 and 15 October 2007,a time during which a series of events were held: a conference, two artistic residencies, seven artists' books, a site dedicated to the project and several interventions in the public space. The project reunited several Romanian artists (Mircea Cantor, Anetta Mona Chişa / Lucia Tkáčová, Nicoleta Esinencu, H.arta, Daniel Knorr, Dan Perjovschi and Lia Perjovschi) who produced a series of temporary interventions in the public space. With the exception of Anetta Mona Chişa and Lucia Tkáčová's video work which was screened in the Cityplex Cinema Bucharest and on more than 200 digital screens indoor and outdoor scattered throughout the city for a month beginning with July 20 , the other interventions took place between the $15^{\text {th }}$ of September and the $15^{\text {th }}$ of October, being accompanied by the publication of two special editions of the Romanian weekly cultural magazines "Suplimentul de Cultură" and "Observatorul Cultural". The works presented in the framework of this project were very different regarding both the artistic media and the messages of the works. The artists aimed to raise awareness regarding some of the issues identified in Romanian post-communist society, such as the discrimination against the Roma population (approached in the theatrical intervention of Nicoleta Enisescu "A(II)RH+"), gender representations (in Anetta Mona Chişa and Lucia Tkáčová's video "What the fuck are you staring at?"), democracy and recent history (Dan Perjovscki's performance "Monument (History/Hysteria 2)"_which took place every day for a week in the University Square, recalling the events that had taken place there during the $13^{\text {th }}$ and the $15^{\text {th }}$ of June 1990, known as "Mineriade"), or Daniel Knorr's intervention "Tram and Institutions", which questioned the role and the status of four of national institutions, the police, the Orthodox Church, the military and the red cross.

Organized by the Goethe-Institut Bukarest in partnership with the Romanian Cultural Institute (ICR) and Allianz Kulturstiftung, the project was initiated as a pilot project with the intention to be continued in the next years as a state supported program. Unfortunately, the state institutions were not interested in funding the project any further, and for this reason, as a protest to the lack of response from them, the E-cart Association, through art critic Raluca Voinea, who was involved in the organizational team, launched in 2009 Departamentul pentru artă în spatiul 
public (The Department of Art in the Public Space) with the aim to continue the discussions about art and the public space, even without the cooperation of state institutions. But for the moment, the activity of this 'department' remains in the form of a manifest.

It is hard to say in measurable results what the outcome of the projects Spatiul Public Bucureşti | Public Art Bucharest 2007 was. If the clear objectives of the projects (the interventions, the artists' books and so on) were realized as the photographic documentation given as proof, the more long-term aims and objectives, such as raising people's awareness with regard to the condition of public space in post-communist Romania, or the importance of the cultural sector for the development of democracy are very hard to evaluate. It is obvious that one or two projects cannot change the existing situation - in order to make a difference, a more long term commitment is needed. Therefore, in this regard, the project failed, as it only remained a pilot project, with no continuity in the following years.

In comparison with the permanent monuments, what the temporary art projects aim to do is not to confirm the existent social or political system or try to offer an idealized and unified image of ourselves and our past, but to voice our differences, to address controversial issues, to bring people together, and to strengthen communities. In this sense, these projects are in line with what the political philosopher Chantal Mouffe calls the "agonistic" public space. Mouffe advocates for the 'agonistic' model of the public space, which is seen not as an arena for drawing a consensus, but as a "battleground where different hegemonic projects are confronted, without any possibility of final reconciliation" (Mouffe, 2008, p. 10). This way, the role of art in public space is very important in questioning the dominant hegemony by "unveiling all that is repressed by the dominant consensus" (Mouffe, 2008, p. 12). Mouffe considers that from the point of view of the hegemonic conception of politics, all artistic practices are more or less political because these practices can only take two positions, either to confirm the "given symbolic order" - and they do so simply by not being against it -, or to challenge it. Thus, the new form of public art tries to challenge the way state institutions exert their power over the public space, to be the voice of difference, but in order to do so, these art projects must make themselves be heard, and in this regard they were not very successful, since the temporary art projects are not well-known outside the art world. We have to wonder why this is happening. Perhaps the main reason is that this form of public art receives no support from the state and thus has difficulties in creating a stronger platform, which would enable the artists and their works to be more visible in the public space, or maybe art should strive to become an "art of the widest possible relevance" (Phillips, 1988, p. 193).

In conclusion, the development of public art in Romania is mainly seen as a battle fought by two parts: on the one hand, we have the permanent sculpture which functions mainly as a means to construct a post-communist national identity, but which allows little innovation and the process behind which is governed by an institutional system that still has roots in the previous communist system; and on the other hand, we have a new form of art, striving to make itself noticed in a society which is also in a continuous struggle with the post-communist condition. 
Acknowledgments: This work was co-financed from the European Social Fund through Sectoral Operational Programme Human Resources Development 2007-2013, project number POSDRU/159/1.5/S/140863, Competitive Researchers in Europe in the Field of Humanities and Socio-Economic Sciences. A Multi-regional Research Network.

\section{REFERENCES}

Bercea, M. (2005). O ofensa: Monumentul Revolutiei. Revista 22. Retirieved from http://www.revista22.ro/o-ofensa-monumentul-revolutiei-1970.html.

Bishop, C. (2012). Artificial Hell. Participatory Art and the Politics of Spectatorship. London, New York: Verso.

Groys, B. (2008). Art Power. Cambridge, London: The MIT Press.

Mouffe, C. (2008). "Art and Democracy / Art as an Agnostic Intervention in the Public Space". In: Art as a Public Issue. Open magazine, no.14. Rotterdam: NAi Publishers. 6-15.

Piotrowski, P. (2012). Art and Democracy in Post-communist Europe. London: Reaktion Books.

Phillips, P. (1988). Out of Order: the public art machine. in Artforum, December. 